\title{
ANALISIS SISTEM DAN PROSEDUR AKUNTANSI PERSEDIAAN PADA CV. TRIJAYA MULIA
}

\author{
Aliadi ${ }^{1}$, Sjamsul Hidayat ${ }^{2}$, \\ aliadiadi13@gmail.com ${ }^{1}$, sjamsulmiqot@gmail.com ${ }^{2}$ \\ 1,2) Universitas Muhammadiyah Surabaya
}

\begin{abstract}
Inventory is the main part of supply chain management which is have big role to control an asset of company. This research analyzes the system and planning of inventory procedures at CV. Trijaya Mulia. This research uses qualitative methods with data collection with triagulation techniques and uses documentation such as the collection of data from records and documents related to inventory. The results of the research are the analysis and design of inventory accounting systems at CV. Trijaya Mulia. So that the company's operations, the system design is more effective and can meet the company's needs, with a good assessment method. Supervision should be carried out so that the company avoids recording errors, losses, and fraudulent actions.
\end{abstract}

Keywords : Inventory, Trigulation, Supply Chain Management,

\begin{abstract}
ABSTRAK
Persediaan merupakan bagian utama dalam management rantai pasok yang berfunsi besar dalam pengelolaan asset perusahaan. Penelitina ini menganalisa system dan perencanan prosedur persediaan barang pada perushaan CV. Trijaya Mulia. Penelitiann ini mengunakan metode kualitatif dengan pengumpulan data dengan teknik triagulasi dan mengunakan dokumentasi yaitu pengumpulan data yang diperoleh melalui catatan atau dokumen yang berhubungan dengan persediaan. Hasil penelitian berupa analisis dan perancangan sistem akuntansi persediaan pada CV. Trijaya Mulia. Sehingga operasional perusahaan, perancangan sistem tersebut lebih efektif dan dapat memenuhi kebutuhan perusahaan, Dengan metode penilaian yang sudah cukup baik. Sebaiknya perlu di lakukan pengawasan agar perusahaan terhidar dari kesalahan pencatatan, kerugian, dan tindakan kecurangan.
\end{abstract}

Kata Kunci : Persediaan ; Trgulation ; Management Rantai Pasokan

Submitted: Maret 2021

Revised: April 2021

Accepted: Mei 2021

Correspondence to

:aliadiadi13@gmail.com. 


\section{PENDAHULUAN}

Pada era globalisasi, perkembangan dunia bisnis semakin meningkat disertai dengan kemajuan teknologi yang telah membawa pengaruh besar terhadap keadaan ekonomi di Indonesia. leh karena itu, penggunaan teknologi informasi dan sistem informasi yang baik dan handal sangat dibutuhkan oleh setiap organisasi atau perusahaan untuk dapat menghasilkan sumber daya informasi yang akurat, relevan, tepat waktu dan up to date, (Muanas, 2014). Persediaan barang dalam perusahaan dagang adalah persediaan yang akan dijual kembali tanpa mengubah bentuk barang tersebut. Sistem menurut Romney dan Steinbart Romneyt mengatakan bahwa sistem merupakan sekumpulan dua atau lebih dari bagian-bagian yang saling terkait satu sama lain, yang bersama-sama mencapai suatu tujuan yang sama. Sistem terdiri dari sub sistem - sub sistem yang lebih kecil yang masing-masing memiliki fungsi tersendiri untuk mendukung sistem yang lebih besar, (Romney dan Steinbart, 2006). Sistem akuntansi persediaan bertujuan untuk mencatat mutasi setiap jenis persediaan yang disimpan. Sistem ini berkaitan erat dengan sistem penjualan, sistem retur penjualan, sistem pembelian, dan sistem retur pembelian.

Pada peneltian ini, penulis melakukan penelitian pada CV. Trijaya Mulia. Perusahaan tersebut bergerak di bidang garmen dengan memproduksi dan memasarkan produk fashion seperti celana, jacket, blouse, kemeja formal, topi dan lain-lain. CV. Trijaya Mulia sering mengalami masalah yaitu belum memiliki sistem dan prosedur akuntansi yang baik dan sering terjadi adanya perbedaan antara data fisik dan data dalam program, dengan adanya masalah tersebut sering membuat kegiatan operasional terhambat. Masalah ini yang akan dievaluasi dan diperbaiki dalam penelitian ini.

\section{TINJAUAN TEORITIS}

\section{Persediaan}

\section{a. Pengertian}

Kieso, dkk (2017:444) menjelaskan bahwa persediaan (inventory) adalah pos-pos aktiva yang dimiliki untuk dijual dalam operasi bisnis normal atau barang yang akan digunakan atau dikonsumsi dalam memproduksi barang yang akan dijual.

\section{b. Karateristik Persediaan}


Menurut Handoko (2003) terdapat beberapa jenis persediaan, di mana setiap jenis memiliki karakteristik khusus dan cara pengelolaannya berbeda, yaitu :

1) Persediaan bahan mentah (raw materials), barang yang dibeli oleh perusahaan untuk digunakan dalam pembuatan barang jadi.

2) Persediaan bahan setengah jadi (work in process inventory), semua barang yang ada dalam proses produksi.

3) Persediaan barang jadi (finish goods inventory), semua barang yang telah selesai diproduksi tetapi belum terjual.

\section{c. Metode pencatatan persediaan}

Menurut Martini, Dkk (2017:250) pada metode pencatatan persediaan terbagi menjadi dua yaitu :

1) Sistem Periodik

Sistem Perodik adalah sistem pencatatan persediaan di mana kuantitas persediaan ditentukan secara periodik yaitu hanya pada saat perhitungan fisik yang biasanya dilakukan secara secara stok opname, untuk menghitung besarnya harga pokok penjualan, entitas mengurangkan persediaan akhir dari total biaya barang tersedia untuk dijual. Dalam sistem periodik, besarnya persediaan akhir ditentukan berdasarkan hasil perhitungan fisik persediaan. Perhitungan fisik persediaan biasanya dilakukan paling sedikit sekali dalam setahun.

2) Sistem Perpetual

Sistem Perpetual adalah sistem pencatatan persediaan di mana pencatatan yang up-to-date terhadap barang persediaan selalu dilakukan setiap terjadi perubahan nilai.

\section{d. Metode penilaian persediaan}

Penilaian persediaan adalah hal yang sangat penting dalam menyusun suatu laporan keuangan. Menurut Rudianto (2015:223-224) bahwa metode penilaian persediaan dibagi menjadi tiga, yaitu :

1) First In First Out (FIFO)

Metode ini merupakan metode di mana barang yang masuk (dibeli atau diproduksi) terlebih dahulu akan dikeluarkan (dijual) pertama 
kali, sehingga yang tersisa pada akhir periode adalah barang yang berasal dari pembelian atau produksi terakhir.

2) Last In First Out (LIFO)

Metode ini merupakan metode di mana barang yang masuk (dibeli atau diproduksi) paling akhir akan dikeluarkan (dijual) terlebih dahulu. Jadi barang yang tersisa pada akhir periode adalah barang yang berasal dari pembelian atau produksi awal periode.

3) Persediaan Rata-rata (AVERAGE)

Dalam menggunakan metode ini, barang yang dikeluarkan maupun barang yang tersisa dinilai berdasarkan rata-rata, sehingga barang yang tersisa pada akhir periode adalah barang yang dimiliki nilai ratarata.

\section{e. Jenis-jenis persediaan}

Martini, dkk (2017:246) menjelaskan beberapa tipe umum persediaan sebagai berikut :

1) Persediaan Bahan Baku (raw material inventory)

Persedian bahan baku merupakan bahan atau pun perlengkapan yang akan digunakan dalam proses produksi.

2) Persediaan Barang Dalam Penyelesaian (work in process inventory) Merupakan barang setengah jadi.

3) Persediaan Barang Jadi (finished goods inventory)

\section{Sistem Akuntansi}

\section{a. Pengertian}

Warren dkk (2017: 230) memberikan definisi mengenai sistem akuntansi (accounting system) sebagai metode dan prosedur untuk mengumpulkan, mengelompokan, merangkum, serta melaporkan informasi keuangan dan operasi perusahaan. Sistem akuntansi berubah melalui tiga proses tahap seiring dengan perkembangan dan perubahan perusahaan. Tiga tahap tersebut adalah tahap 1. Menganalisis kebutuhan pihak-pihak yang menggunakan informasi tahap 2. Sistem dirancang untuk dapat memenuhi kebutuhan penggunanya, dan tahap 3. Sistem ini kemudian diterapkan dan digunakan. 
Mulyadi (2016:2) menjelaskan bahwa sistem pada dasarnya adalah sekelompok unsur yang erat berhubungan satu dengan lainnya, yang berfungsi bersama-sama untuk mencapai tujuan tertentu. Dari definisi ini dapat dirinci lebih lanjut pengertian umum mengenai sistem sebagai berikut:

1. Setiap sistem terdiri dari unsur-unsur. Sistem pernapasan kita terdiri suatu kelompok unsur, yaitu hidung, saluran pernapasan, paru-paru, dan darah. Unsur-unsur suatu sistem terdiri dari subsistem yang lebih kecil, yang terdiri pula dari kelompok unsur yang membentuk subsistem tersebut.

2. Unsur-unsur tersebut merupakan bagian terpadu sistem yang Bersangkutan. Unsur-unsur sistem berhubungan erat satu dengan lainnya dan sifat serta kerja sama antar unsur sistem tersebut mempunyai bentuk tertentu.

3. Unsur sistem tersebut bekerja sama untuk mencapai tujuan sistem. Setiap sistem mempunyai tujuan tertentu. Sistem pernapasan kita bertujuan untuk menyediakan oksigen, dan pembuangan karbon dioksida dari tubuh kita bagi kepentingan kelangsungan hidup kita. Unsur sistem tersebut yang berupa hidung, saluran pernapasan, paru-paru, dan darah bekerja sama satu dengan lainnya dengan proses tertentu untuk mencapai tujuan diatas.

4. Suatu sistem merupakan bagian dari sistem lain yang lebih besar. Sistem pernapasan kita merupakan salah satu sistem yang ada dalam tubuh kita, yang merupakan bagian dari sistem metabolisme tubuh. Contoh sistem lain adalah sistem pencernaan makanan, sistem peredaran darah dan sistem pertahanan tubuh.

\section{b. Tujuan umum pengembagan sistem akuntansi}

Tujuan umum pengembagan sistem akuntansi menurut Mulyadi (2016:15) adalah sebagai berikut :

1. Untuk menyediakan informasi bagi pengelolaan kegiatan usaha baru

2. Untuk memperbaiki informs yang dihailkan oleh sistem yang sudah ada

3. Untuk memperbaiki pengendalian akuntansi dan audit internal

4. Untuk mengurangi biaya klerikel dalam penyelenggaraan catatan akuntansi 


\section{c. Sistem akuntansi persediaan}

Menurtu Mulyadi (2016:469) Sistem dan prosedur yang terkait dengan sistem akuntnasi persediaan adalah sebagai berikut :

\section{Prosedur pencatatan produk jadi}

Prosedur ini merupakan salah satu prosedur dalam sistem akuntansi biaya produksi. Dalam prosedur ini dicatat harga pokok produk jadi yang debit kedalam akun persediaan produk jadi dan dikerdit kedalam akun barang dalam proses. Adapun dokumen sumber yang dibutuhkan dalam prosedur pencatatan produk jadi adalah laporan seleksi dan bukti memorial.

\section{Prosedur pencatatan harga pokok produk jadi yang dijual}

Mulyadi (2016:471) adalah sebagia berikut. Prosedur ini merupakan salah satu dari prosedur dalam sistem penjualan, adapun prsedur lainya seperti prosedur order penjualan, prosedur persetujuan kredit, prosedur pengiriman barang, prosedur penagihan, dan prosedur pencatatan piutang. Dokemun yang digunakan untuk mencatat transaksi penjualan produk jadi yaiitu surat order pengiriman dan faktur penjualan.

\section{Prosedur Pencatatan Harga Pokok Produk jadi yang Diterima} Kembali dari Pembeli

Mulyadi (2016:472) adalah sebagai berikkut. jika produk yang telah dijual dikembalikan oleh pembeli, maka transakasi retur penjualan ini akan mempengaruhi persediaan produk jadi, yaitu menambah kuantitas produk jadi dalam kartu gudang yang akan diselengarakan oleh bagian gudang dan dapat menambah kuantitas dan harga pokok produk jadi yang di catat oleh bagian kartu persediaan yaitu dalam kartu persediaan produk jadi. Dokumen yang digunakan dalam prosedur perncatatan harga pokok produk jadi yang dikembalikan oleh pembeli adalah laporan penerimaan dan memo kredit.

\section{Prosedur Penctatan Harga Pokok Persediaan Produk Dalam Proses}

Mulyadi (2016:473) adalah sebagai berikkut. Pencatatan persediaan produk dalam proses umumnya dilakukan oleh perusahaan pada akhir 
periode, pada saat dibuatnya laporan keuangan bulanan dan laporan keuangan tahunan.

\section{Prosedur pencatatan harga pokok persediaan yang dibeli}

Mulyadi (2016:477) proses ini merupakan salah satu prosedur yang membentuk sistem pembelian. Dalam prosedur ini dicatat harga pokok persediaan yang dibeli. Dokumen sumber yang digunakan dalam prosedur pencatatan harga pokok persediaan yang dibeli yaitu laporan penerimaan barang dan bukti kas keluar.

6. Prosedur pencatatan harga pokok persediaan yang dikembalikan kepada pemasok

Mulyadi (2016:479) adalah sebagai berikkut. Jika persediaan yang telah dibeli dikembalikan kepada pemosk, maka transakasi reutur pembelian ini akan memengaruhi persediaan yang bersangkutan, yaitu mengurang jumlah kuantitas persediaan dalam kartu gudang yang diselengarakan oleh bagian gudang dan menguranggi kuantitas dan harga pokok persediaan yang dicatat oleh bagian kartu persediaan dalam kartu persediaan yang bersangkutan. Dokum-dokumen yang diperlukan dalam prosedur pencatatan harga pokok persediaan yang dikembalikan kepada pemsok adalah laporan pengiriman barang dan memo debit.

\section{Prosedur permintaan dan pengeluaran barang gudang}

Mulyadi (2016:481) adalah sebagai berikkut. Prosedur ini merupakan salah satu perosedur yang membentuk sistem akuntansi biaya produksi. Dalam prosedur ini dicatat harga pokok persediaan bahan baku, bahan penolong, bahan habis pakai pabrik, dan suku candang yang di pakai dalam kegiatan produksi dan kegiatan non produksi. Dokumen sumber yang di pakai dalam prosedur ini adalah bukti permintaan dan pengeluaran barang gudang ini dipakai oleh bagian gudang untuk mencatat pengurangan persediaan karena pemakaian interen.

\section{Prosedur pengembalian barang gudang}

Mulyadi (2016:482) adalah sebagai berikut. Transakasi pengembalian barang gudang mengurangi biaya dan menambah persediaan barang 
di gudang. Jurnal yang akan dibuat untuk mencatat transakssi dalam jurnal umum adalah sebagi berikut :

Persediaan bahan baku $\mathrm{XXX}$

Persediaan bahan penolong $\mathrm{xxx}$

Persediaan bahan habis pakai pabrik $\mathrm{XXX}$

Persediaan suku cadang $\mathrm{XXX}$

$\begin{array}{lc}\text { Barang dalam proses-bahan baku } & x x x \\ \text { Biaya overhead Pabrik sesungguhnya } & x x x \\ \text { Beban administrasi dan umum } & x x x \\ \text { Beban pemasaran } & x x x\end{array}$

Dokumen yang diperlukan dalam prosedur pengembaliaan barang gudang adalah bukti pengembaliaan barang gudang. Dokumen ini digunakan oleh bagiaan gudang untuk mencatat tambahan kuantitas persediaan ke dalam kartu gudang.

\section{Sistem penghitungan fisik persediaan}

Mulyadi (2016:483) dalam sistem akuntansi persediaan dagang metode mutasi persediaan (perpetual inventory method), di bagian kartu persdiaan diselenggarakan catatan akuntansi berupa kartu persediaan (inventory leger) yang digunakan untuk mencatat mutasi setiap jenis persediaan yang disimpan di bagian gudang. Bagian kartu persediaan yang bertanggungjawab atas terselenggaranya catatan akuntansi yang dapat diandalakan (reliabel) mengenai persediaan yang disimpan di bagian gudang, sedangkan untuk bagian gudang bertanggung jawab atas penyimpanan fisik persediaan di gudang. Dikarenakan kondisi barang yang kemungkinan akan mengalami kerusakan dalam penyimpanan atua karena kemungkinan terjadinya pencurian terhadap barang yang disimpan digudang, maka secara periodik catatan persediaan yang diselanggarakan di bagian kartu persediaan harus dicocokan dengan persediaan yang secara fisik ada di gudang.

Sistem penghitungan fisik persediaan umumnya diguanakan oleh perusahaan untuk menghitung secara fisik persediaan yang disimpan di gudang, yang hasilnya akan digunakan untuk meminta 
peratanggungjawaban bagian gudang mengenai pelaksanaan fungsi penyimpanan, dan sebagai pertanggungjawaban bagian kartu persediaan mengenai kendala mencatat persediaan yang diselenggrakan, serta untuk melakukan penyesuaian (adjustment) terhadap catatan persediaan yang berada di bagian kartu persediaan. Dokumen yang digunakan untuk merekam, meringkas, dan membukukan hasil perhitungan fisik persediaan adalah sebagai berikut :

1. Kartu perhitungan fisik (inventory tag).

2. Daftar hasil perhitungan fisik (inventory summary sheet).

3. Bukti memorial.

Catatan akuntasi yang digunakan dalam sistem perhitungan fisik persediaan adalah :

1. Kartu persediaan

Kartu persediaan. Yaitu catatan akuntansi yang digunakan untuk mencatat penyesuaian terhadap dan persediaan (kuantitas dan harga pokok total) yang tercatum dalam kartu persediaan oleh bagian kartu persediaan, berdasarkan hsil penghitungan fisik persediaan.

2. Kartu gudang

Catatan ini digunakan untuk mencatat penyesuaian terhadap data persediaan (kuantitas) yang tercantum dalam kartu gudang yang diselenggarakan oleh bagian gudang, berdasarkan hasil penghitungan fisik persediaan.

3. Jurnal umum

Dalam sistem perhitungan fisik persediaan, jurnal umum digunakan untuk mencatat jurnal persediaan atas akun persediaan Karena adanya perbedaan antara salado yang dicatat dalam akun persediaan dengan saldo menurut perhitungan fisik.

Fungsi yang dibentuk untuk melaksanakan perhitugan fisik persediaan umumnya bersifat sementara, yang biasanya berbentuk beupa panitia atau komite, yang anggotanya dipilhkan dari karyawan yang tidak menyelanggarakan catatan akuntansi persediaan dan tidak melaksanakan fungsi gudang., adapun panitia penghitung fisik persediaan terdiri dari: 
1. Pemegang kartu penghitungan fisik.

2. Penghitung.

3. Pengecek.

Untuk itu fungsi yang terkait dalam sistem perhitungan fisikpersediaan adalah :

1. Paniti perhitungan fisik persediaan.

2. Fungsi akuntansi.

3. Fungsi gudang.

Unsur pengendalian interan dalam sistem perhitungan fisik persediaan digolongkan ke dalam tiga kelompok

1. Organisasi

a. Perhitungan fisik persediaan harus dilakukn oleh panitia yang terdiri dari fungsi pemegang kartu perhitungan fisik, fungsi perhitungan, dan fungsi pengecek.

b. Panitia yang dibentuk harus berasal dari karyawan selain karyawan fungsi gudang dan fungsi akuntansi persediaan, dikeranakan karyawan di kedua fungsi inilah yang justru dievaluasi atas kinerjanya atas persediaan.

2. Sistem organisasi dan prosedur pencatatan

a. Daftar hasil perhitungan fisik persediaan ditandatangani oleh ketua perhitungan fisik.

b. Daftar hsil perhitungan fisik persediaan ditandatangani oleh kartu panitia perhitungan fisik.

c. Pencatatan hasil perhitungan fisik persediaan didasarkan atas karutu perhitungan fisik yang telah diteliti kebenarannya oleh pemegang kartu perhitungan fisik.

d. Harga satuan yang dicatat dalam daftar hasil perhitungan fisik berasal dari kartu persediaan yang bersangkutan.

e. Penyesuaian terhadap kartu persediaan didasarkan pada informai (kuantitas maupun harga pokok total) setiap jenis persediaan yang tercantum dalam daftar perhitungan fisik.

3. Praktik yang sehat

a. Kartu perhitungan fisik bernomor urut tercatat dan penggunaannya dpertanggungjawabakan oleh fungsi pemegang kartu perhitungan fisik. 
b. Dalam perhitungan fisik setiap jenis persediaan dilakukan dua kali secara independen, pertama kali oleh penghitung dan keduai kali oleh pengecek.

c. Kuantitas dan data persediaan yang tercantum dalam kartu perhitungan fisisk dicocokan oleh fungsi pemegang kartu perhhitunggan fisik sebelum data yang tercantum dalam kartu perhitungan fisik dicatat dalam daftar hasil perhitungan fisik.

d. Adapun peralatan dan metode yang digunakan mengukur dan menghitung kuantitas persediaan haru dijamin ketelitiannya.

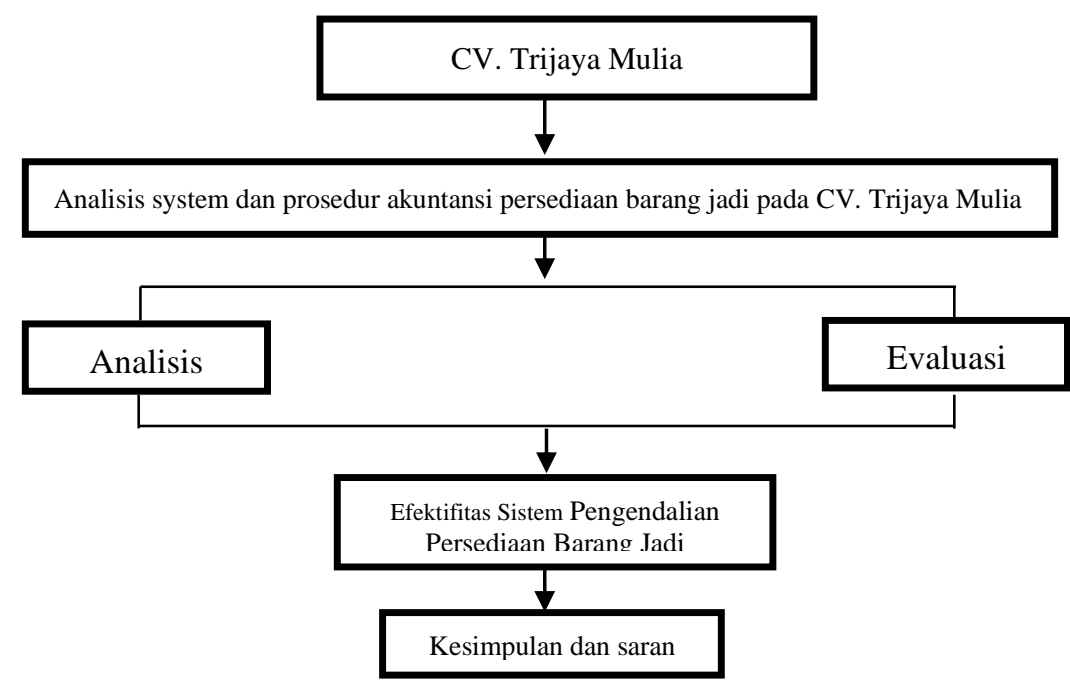

Gambar 1. Kerangka Konseptual

\section{METODE PENELITIAN}

\section{Jenis Penelitian}

Dalam penelitian ini, data yang digunakan adalah data kualitatif, yaitu data yang berupa gambaran umum perusahaan dan data catatan persediaan berupa bagan alir dari CV. Trijaya Mulia.

\section{Pengumpulan Data}

Dokumen yang diperlukan adalah dokumen yang berhubungan dengan persediaan yaitu berupadata flowchard.

\section{Tahapan Analisis}


Triangulasi teknik, berarti peneliti harus menggunakan teknik pengumpulan data yang berbeda-beda untuk mendapatkan data dari sumber yang sama.

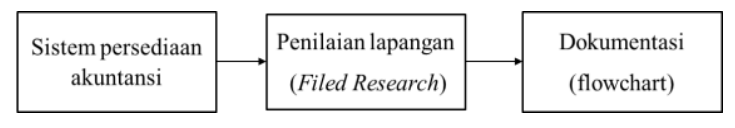

Gambar 2. Bagan alur penelitian

Adapun beberapa tahap penelitian yang akan Penulis lakukan yaitu,

1. Melakukan dokumentasi pada CV. Trijaya Mulia untuk mendapatkan informasi perusahaan.

2. Mengalisis Sistem dan prosedur Akuntansi Persediaan.

3. Menganalisa stok, bukti penerimaan barang, sales order, faktur penjualan, surat jalan, surat return penjualan dan diagram alur produk.

4. Merancang prosedur sistem persediaan yang sesuai untuk perusahaan $\mathrm{CV}$. Trijaya Mulia.

\section{HASIL PENELITIAN DAN PEMBAHASAN}

\section{Alur persediaan barang CV. Trijaya Mulia}

a. Proses ini adalah proses dimana barang masuk dari penjahit atau suplayer yang berupa barang jadi yang akan di di cek oleh bagian produkasi.

b. Di proses ini bagian bagian produksi melaukan pemeriksaan atau quality control agar barang yang masuk gudang sesuai dengan permintaan dan bagian produksi membuat surat tanda terima 3 rangkap yang akan diberikan ke bagian admin gudang, penjualan, dan untuk bagian produksi itu sendiri.

c. Setelah itu bagian logistic memasukan barang ke gudang dan membuat kartu stock, dan bagian admin ggudang melakukan input stok ke program.

d. Berikutnya bagian logistic memberikan contoh barang ke sales agar biasa ditawarkan ke pembeli.

e. Apabila ada orderan maka pihak sales akan memberikan data barang yang di pesan ke bagian admin penjulalan. 
f. Seteleah itu admin penjualan membuat SO (sales order) sesuai dengan permintaan sales, dan memberikan SO kebagian admin gudang khusnya kepala gudang.

g. Berikutnya kepala gudang memberikan SO tersebut ke bagian logistic agakr barang yang di minta dapat di siapakan oleh pihak loggistik.

h. Setelah selesai di siapkan pihak admin gudang mengembalikan SO ke admin penjualan agak bisa dibuatkab nota.

i. Setelah selesai di siapkan pihak admin gudang atau kepala gudang melakukan pengecekan apakah barang yang di siapkan sudah sesuai dengan permintaan.

j. Setelah pengecekan yang berikutnya adalah peking yang di awasi langsung oleh pihak admin gudang atau kepal gudang.

k. Berikutnya pihak admin gudang membuatkan surat jalan 3 rangkap yang pertama untuk admin gudang, penjualan, dan expedisi. Dan diserahkan ke kepala gudang agar barang tersbut dapat langsung dikirimkan.

\section{Bagan alir CV. Trijaya Mulia}

alur persediaan yang ada di perusahaan CV. Trijaya Mulia yang dibuat oleh penulisi melaui pengumpulan data dan wawancara langsung di lapangan disajikan dalam gambar 3.

\section{Klasifikasi persediaan barang pada CV. Triaya Mulia}

Persediaan merupakan salah satu unsur yang paling efektif dalam kegitan perusahaan dagang maupun manufaktur karena hampir seluruh pendapatanya diperoleh dari penjualan barang sebagai persediaan yang secara terus menerus diperoleh, diubah, dan kemudian di jual kembali. Kalsifikasi persediaan pada CV. Trijaya Mulia terdiri dari persediaan barang dagang atau barang jadi yang langsung dijual kekonsumen. Berikut adalah jenis-jenis persedian menurut kondisinya dan jenis persediaan untuk kebutuhan sehari-hari.

Jenis-jenis perseadian yang dimiliki CV. Trijaya Mulia menurut kondisinya adalah sebagai berikut :

a. Persediaan barang jadi digudang, yaitu persedian yang disimpan digudang sebelum dijual.

b. Konsinasi ya itu barang jadi atau barang siap dijual yang di titipkan di maal, tooktoko. 
c. Persediaan rusak atau cacat adalah perseediaan yang di simpan digudang lalu di pilah kembalih apakah masih layak dijual dengan harga rendah atau di buang.

Gambar 3. Bagan Alir CV. Trijaya Mulia

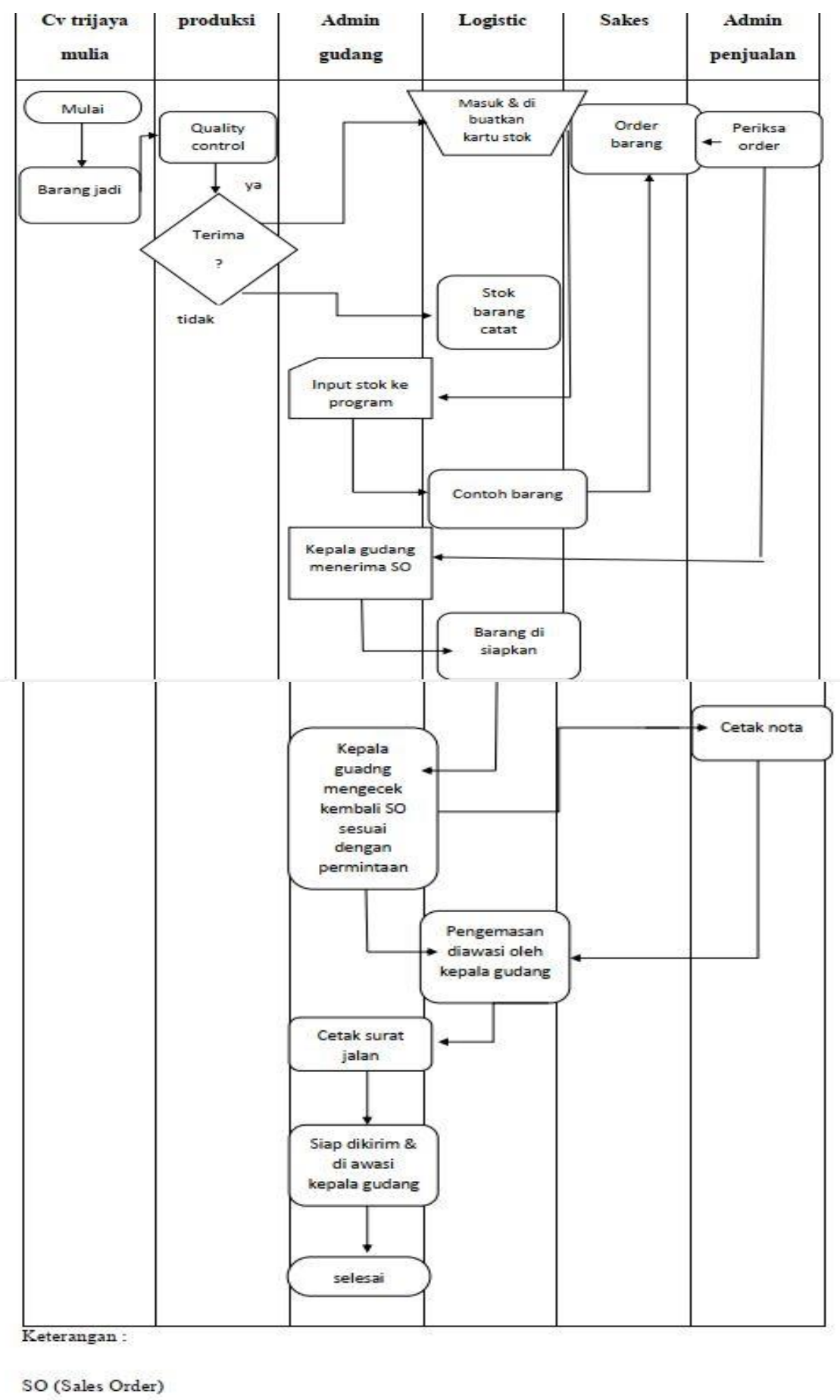




\section{Sistem Akuntansi Persediaan Barang pada CV. Trijaya Mulia}

\section{a. Unit-unit Yang Terkait}

Sistem akuntansi persediaan barang melibatkan unit organisasi terkait, mulai dari masuknya barang sampai pencatatan akuntasi. Dalam pelaksanaannya unit organisasi tersebut saling berhubungan dan bekerja sama dengan yang lain sehingga dapat terselengaranya suatu sistem akuntansi persediaan barang yang baik. Unit-unit organisasi dalam sistem akuntasi persediaan pada CV. Trijaya Mulia adalah sebagai berikut :

1. Bagian Gudang, bagian ini bertangung jawab untuk mengalokasikan perseddiaan yang masuk ke gudang agar sesuai dengan kelompoknya serta barang yang keluar dari gudang.

2. Bagian administrasi, bagian ini bertugas memproses permintaan penjualan persediaan, lalu di teruskan ke pihak gudang agar bisa langsung dikerjakan.

3. Bagian Akuntansi, bagian ini jua di lakukan oleh bagian administrasi, bagian ini dibagi menjadi dua bagian yaitu bagian pemasukan dan pengeluaran. Bagian pemasukan bertugas mencatat persediaan yang masuk kedalam sistem komputer, sedangkan bagian pengeluaran mencatat kewajiban yang terkait dengan pembelian.

\section{b. Sistem pencatatan persediaan}

Cv. Trijaya Mulia dalam melakukan pencatatan persediaan dengan metode perpetual dengan system komputerais, sehingga perusahaan dapat mengetahui jumlah persediaan yang ada setiap saaat karena catatan persediaan mampu menyajikan data dari setiiap transaksi pemasukan maupun pengeluaran barang dagang secara lengkap dan akurat.

Data persediaan yan ada digudang langsung dicatat dalam sistem komputer perusahaan barang masuk atau keluar. Pencatatan pembelian ini dilakukan apabila barang yang di pesan telah diterima oleh pihak gudang dan dokumen dasar pencatatan adalah faktur pembelian.

\section{c. Metode Penilaian Persediaan}

$\mathrm{CV}$. Trijaya Mulia mengunakan metode Average sebagai metode yang digunakan dalam penilaian. Dalam metode average membagi antara biaya barang yang tersedia untuk dijual dengan jumlah unit yang tersedia. Sehingga persediaan akhir dan beban pokok penjualan dapat dihitung dengan harga rata-rata. Dalam metode 
average perusahaan akan menggunakan persediaan barang yang ada digudang untuk dijual tanpa memperhatikan mana yang masuk lebihi dulu atau akhir.

\section{d. Prosedur yang membentuk sistem persediaan}

1. Prosedur harga pokok persediaan

Dalam peoses pencatatan harga pokok persediaan, bagian admin gudang meminta pada bagian produksi untuk produksi barang dagang, setelah diproduksi barang di kirimkan ke bagian gudang dan bukti penerimaan barang diserahkan kebagian gudang bersama dengan barang dan dibukukan dalam buku gudang serta diserahkan kebagian akuntasi pencatatan persediaan. Selanjutnnya mengadakan pembukuan persediaan berdasar bbukti penerimaan barang.

2. Penghitungan Fisik persediaan

Pelaksanaan perhitungan fisik persediaan pada akhir bulan. Dalam perhitungsn ini terdiri dari perhitungan dan pengecekan. Dimana perhitungan berasal dari bagian gudang yang melakukan perhitungan yang berasal dari buku gudang dan mencatat hasilnya dalam kartu perhitungan fisik. Pengcek melakukan perhitugan ulang, mencatat hasilnya dalam kartu perhitungan fisik dan memberi tanda pada persediaan yang telah dihitung. Apabila terdapat ketidak sesuaian antara hasil perhitungan yang dilakukan panghitung dan pengcek, maka dilakukan perhitungan persediaan ulang. Setelah itu membuat laporan hasil perhitungan dan menyerahkannya kebagian akuntansi, untuk dicantumkan harga pokok persediaan yang telah dihitung. Laporan tersebut igunakan oleh bagian gudang untuk melakukan penyesuaian dengan buku gudang, digunakan juga oleh bagian akuntansi untuk mengadakan penyesuaian dengan buku persediaan. Laporan hasil perhitungan fisik persediaan diserahkan kebagian administras.

Dokumen yang digunakan dalam perhitungan fisik persediaan adalah sebagai berikut.

a. Kartu perhitungan fisik

Kartu ini diguanakan untuk mencatat perhitungan fisik persediaan, terdiri dari tiga bagian. Dalam perhitungan fisik, setiap jenis persediaan dihitung dua kali 
oleh penghitung dan pengcek. Perhitungan mengunakan bagian ketiga katu perhitungan fisik uantuk mencatat hasil perhitungan, sedangkan bagian kedua digunakan oleh pengecek dan bagian pertama digunakan untuk memberi tanda pada persediaan yang telah dihitung.

b. Laporan hasil perhitungan fisik

Laporan perhitungan fisik digunakan untuk mencatat hasil penghitungan yang terdapat pada kartu penghitung fisik. Catatan yang digunakan dalam perhitungan fisik persediaan adalah buku gudang, buku persediaan, dan buku jurnal.

\section{Sistem akuntansi persediaan pada CV. Trijaya Mulia adalah sebagai berikut :}

1. Unit-unit yang terkait dalam persediaan barang pada CV. Trijaya Mulia melibatkan bagian gudang, bagian administrasi serta bagian akuntansi. Dalam pelaksanaanya masing-masing unit organisasi tersebut saling berhubungan dan bekerja sama dengan yang lainya sehingga dapat terselengara suatu system akuntansi persediaan yang baik. Perbedaan fungsi yang berkaitan dengan sistem akuntansi persediaan barang tergantung pada luas wewenang dan tugas masingmasing.

2. Dalam penilain sistem yang di pakai untuk pencatatan persediaan, CV Trijaya Mulia mengunakan metode perpetual dengan sistem komputerisasi. Metode ini digunakan dengan alasan, karena banyaknya jenis barang yang di jual, sehingga memerlukan sistem pencatatan yang selalu dapat memberikan informasi tentang persediaan baik dari jumlah unit, harga perolehan perolehan per unitdan total nilai persediaan yang dimiliki. Pemilihan metode ini cukup efektif, apabila perusahaan mengunakan metode persediaan fisik maka akansulit diketahui jumlah persediaan yang siap digunakan, karena dalam metode persediaan fisik yang dicatat hanya penambahanjumlah persediaan sedangkan pemakaian persediaan tidak dicatat. Apabila terjadi penambahan jumlah produksi tidak dapat diketahui berapa persediaan yang ada digugdang yang siap untuk digunakan karena dalam metode persediaan fisik jumlah persediaan yang ada digudang dapat diketahui apabila telah dilakukan penghitungan fisik. Pencatatan dimulai dari pencatatan terhadap adanya barang masuk dan barang keluar transaksi ini paling sering terkjadi dalam operasional perusahaan. Pengunaan metode 
perpetual ini dapat memudahkan pihak perusahaan untuk mengetahui persediaan barang dengan cepat jika sewaktu-waktu dibutuhkan tanpa harus menghitung persediaan barang dagang yang ada digudang.

3. Penggunaan metode average perusahaan yaitu persediaan barang yang ada digudang untuk dijual tanpa memperhatikan mana yang masuk lebihi dulu atau akhir. Prosedur pencatatan harga pokok produk yang dijual Belum sesuai dokumen yang digunakan masih kurang yaitu surat order pengiriman dan faktur penjualan, sedangkan untuk prosedur yang lain sudah sesai. dan di CV. Trijaya Mulia belum ada atua belum membuat flowchart untuk proseduranya, yang ada hanyalah bagan alir, sehinga yang digunakan di perusahan $\mathrm{CV}$. Trijaya Mulia adalah bagan alir saja.

\section{KESIMPULAN}

Berdasarkan hasil pembahasan diatas dapat disimpulkan bahwa :

1. Sistem akuntansi persediaan pada CV. Trijaya Mulia cukup efektif. Ini dapat dilihat dari adanya pemisahaan tugas antara unit-unit organisasi. Tetapi tidak ada sistem dan prosedur pada pencatatan harga pokoko produk yang dijual masih belum lengkap, dokumen yang digunakan yaitu kartu gudang, surat order pengiriman dan faktur penjualan.

2. Sistem persediaan akuntansi CV. Trijaya Mulia belum sesuai dengan sistem dan prosedur akuntansi persediaan yang berlaku, dikarenakan masih menggunakan bagan alir dalam pelaksanaan sistem dan prosedurnya, dan dalam pengendalian interen masih kurang baik yang menyebabkan terjadinya selisih antara stok fisik dan stok data konmputer yang disesebabkan karena adanya input data dobel keran kurangnya pengawasan.

\section{SARAN}

1. Untuk CV. Trijaya Mulia sistem akuntansi persediaan barang dagang dan metode pencatatan barang yang selama ini telah diterapkan agar terus di pertahankan. dan di lengkapi dokumen pada masing-masing sistem prosedur akuntansi persediaan dan secara berkala membuat flowchart yang dapat bermanfaat untuk arsip perusahaan dan biasa di jadikan media belajar untuk karyawan baru. 
2. Dengan metode penilaian yang sudah cukup baik. Sebaiknya perlu di lakukan pengawasan agar perusahaan terhidar dari kerugian dan tindakan kecurangan.

\section{DAFTAR PUSTAKA}

Andini Tirta Cricela Suleman (2017) “Analisis Sistem Informasi Akuntansi Persediaan Pelumas", PT. Fajar Indah Kusuma

Daranatha (2009) "Sistem Informasi Akuntansi." Jakarta: Salemba Empat.

Daranatha (2009) "Sistem Informasi Akuntansi." Jakarta: Salemba Empat.

Faujan Otinur (2017) “Analisis Sistem Informasi Akuntansi Dan Sistem Pengendalian Internal Persediaan Barang Pada Toko Campladean Manado“.

Gitosudarmo, I. dan basri (2002) “Manajemen Keuangan.” Yogyakarta: BPFE-Yogyakarta.

Gitosudarmo, I. dan basri (2002) “Manajemen Keuangan.” Yogyakarta: BPFE-Yogyakarta.

Kieso M. Donald E. Jerry J. dan Terry D. Warfield. (2017) “intermediate Accounting.” Ney York: hon Wiley and Sons Inc.

Kieso M. Donald E. Jerry J. dan Terry D. Warfield. (2017) “intermediate Accounting.” Ney York: hon Wiley and Sons Inc.

Miktam Ssatria Nugraha (2018) Analisis sistem informasi Akuntansi persediaan bahan baku. "Loh Jinawi Coffee And Bean"

Muanas (2018) “Analisis sistem informasi akuntansi persediaan terhadap pengelolaan persediaan barang dagang pada pt winner textile," (October).

Muanas (2018) “Analisis sistem informasi akuntansi persediaan terhadap pengelolaan persediaan barang dagang pada pt winner textile," (October).

Mulyadi (2016) “Sistem Akuntnasi." Jakarta Selemba Empat.

Reeve (2009) “Pengantar Akuntansi Adaptasi Indonesia.” Jakarta: Salemba Empat.

Reeve (2009) "Pengantar Akuntansi Adaptasi Indonesia." Jakarta: Salemba Empat.

Steinbart, R. (2016) “Sistem Informasi Akuntansi.” Jakarta: Salemba Empat.

Steinbart, R. (2016) “Sistem Informasi Akuntansi.” Jakarta: Salemba Empat.

Sulindawati (2017) “Manajemen Keuangan Sebagai Dasar Pengambil Keputusan Bisnis.” Depok: PT. Raja Grafindo Persada.

Sulindawati (2017) “Manajemen Keuangan Sebagai Dasar Pengambil Keputusan Bisnis.” Depok: PT. Raja Grafindo Persada. 
Warren, Reeve, James, J. (2016) “Financial and Managerial Accounting." US

Warren, Reeve, James, J. (2016) “Financial and Managerial Accounting." USA. 